\title{
Potential Benefits of Acupuncture and Herbs for Obesity-Related Chronic Inflammation by Adipokines
}

\author{
Ji-Youn Kim, ${ }^{1}$ Seon-Eun Baek, ${ }^{1}$ Rehna Paula Ginting, ${ }^{2}$ Min-Woo Lee $\mathbb{D}{ }^{2}$ \\ and Jeong-Eun Yoo $\mathbb{D}^{1}$ \\ ${ }^{1}$ Department of Korean Medicine Obstetrics \& Gynecology, College of Korean Medicine, Daejeon University, 62, Daehak-ro, \\ Dong-gu, Daejeon 34520, Republic of Korea \\ ${ }^{2}$ Department of Integrated Biomedical Science and Soonchunhyang Institute of Medi-bio Science (SIMS), \\ Soonchunhyang University, Cheonan-si, Chungcheongnam-do 31151, Republic of Korea
}

Correspondence should be addressed to Min-Woo Lee; mwlee12@sch.ac.kr and Jeong-Eun Yoo; jeyoo@dju.ac.kr

Received 23 April 2020; Revised 3 September 2020; Accepted 21 September 2020; Published 9 October 2020

Academic Editor: Yuan Xu

Copyright (C) 2020 Ji-Youn Kim et al. This is an open access article distributed under the Creative Commons Attribution License, which permits unrestricted use, distribution, and reproduction in any medium, provided the original work is properly cited.

\begin{abstract}
The adipose tissue is an organ that stores energy in the form of fats. It also has been known as an endocrine playing an integral role in metabolic homeostasis by secreting various adipokines. In obesity, the adipokine components and secretion patterns are altered toward proinflammation with weight gain, causing low chronic inflammation, which is closely linked to various metabolic diseases. Acupuncture and herbs are used for the management of obesity and its comorbidities, and it has been observed that these therapies affect the amount of expression and concentration of adipokines with improved metabolic phenotypes in both animal and human metabolic diseases. In this review, we discuss the role of adipokines and summarize beneficial effects of the treatments such as electroacupuncture, pharmacopuncture, catgut embedding acupuncture, and single and multiple medicinal herbs on obesity and its relations to adipokine composition. It will provide a new insight for applying adipokines as surrogate markers in complementary and alternative medicine practice.
\end{abstract}

\section{Introduction}

The World Health Organization (WHO) defines overweight and obesity as a condition involving accumulation of excess body fat. Specifically, in Western, it regards a body mass index (BMI) equal to or greater than 30 as obese and a BMI of 25 as overweight. According to the WHO statistics, in the US, the percentage of the population with BMI equal to or greater than 30 has increased from $11.9 \%$ in 1975 to $36.2 \%$ in 2016; during the same period, this percentage has increased from $0.6 \%$ to $4.7 \%$ in South Korea. These statistics indicate that the prevalence of obesity has increased considerably over the past 40 years [1].

Obesity is an important health issue that causes a wide range of metabolic diseases, necessitating proper treatment and management strategies [2]. In the previous study, complementary and alternative medicine, such as electroacupuncture and catgut embedding acupuncture, represents an efficient therapeutic option for obesity control [3]. Obesity is a low-grade chronic inflammatory disease characterized by an excess accumulation of visceral fat especially white adipose tissue (WAT). Increased WAT mass is known to induce the secretion of proinflammatory mediators including TNF-a and IL-6, resulting in an imbalance in the production of anti-/proinflammatory cytokines [4]. In this review, we searched for studies on acupuncture and herbs regarding to adipokines and presented the main results of English publications obtained from PubMed database and data from works published in Korean language. Those articles which were not relevant to obesity or metabolic disorder were excluded. We accounted for the role of adipokines and introduced several studies regarding the beneficial effects of acupuncture and herbs on metabolic disorders and relations with adipokine composition. 


\section{Chronic Inflammation and Obesity}

The development of obesity is closely correlated with the alterations of the immune profile, leading to chronic lowgrade inflammation. This state of inflammation is distinguished from general inflammation by different features that the body does not show common signs of inflammation; however, they share similar inflammatory mediators and signaling pathways disorders [5, 6]. Although the issue how obesity causes chronic low-grade inflammation is not yet clear, interesting hypotheses have been proposed. During obesity, adipocytes undergo hypertrophy that leads to an increase of adipose tissue size followed by hypoxia conditions, which contribute to the secretion of proinflammatory adipokines, such as TNF $\alpha$, TGF $\beta$, IL- 6 , and MCP- 1 by adipocytes and other cells present in adipose tissue [7-13]. The release of these inflammatory adipokines can attract immune cells such as macrophages and $\mathrm{T}$ cells to infiltrate into adipose tissue, which is responsible for adipose tissue inflammation $[10,14]$. On the other hand, excessive nutrients input triggers an unfolded protein response (UPR) pathway including inositol-requiring enzyme 1 (IRE1), PKR-like endoplasmic-reticulum kinase (PERK), and activating transcription factor 6 (ATF6) in endoplasmic reticulum (ER) that leads to the activation of JNK (c-Jun aminoterminal kinase) and IKK- $\beta$ - (inhibitor of nuclear factor-kB kinase- $\beta$ ) dependent inflammatory cascades [15]. Understanding the correlation between obesity and chronic low-grade inflammation can be a potential therapeutic target for the treatment of obesity-related metabolic diseases.

\section{The Role of Adipokines}

3.1. Adipose Tissue and Adipokines. White adipose tissue (WAT) is not only an energy storage organ but is also involved in metabolic activities throughout the body by releasing various proteins called adipokines $[16,17]$. WAT is primarily distributed beneath the skin and around internal organs. And it is also observed in various organs, including the heart, kidneys, lungs, and adventitia, in an obese individual; metabolic processes associated with these organs are extensively affected by adipokines released from adipose tissues $[18,19]$. For example, although leptin and adiponectin released by adipose tissue are mainly known for their roles in appetite and energy metabolism, they also demonstrate a substantial influence on the immune system. Moreover, type 2 diabetes is speculated to develop as these influences block the body's insulin signals to cause insulin resistance. Ongoing research has provided evidence that the process in which obesity causes a metabolic disease is related to the irregular or excessive release of adipokines [20].

For a last decade, novel function of adipocytes has been investigated that unlike WAT, rather dissipate nutrient as heat. Based on their developmental origin and location in body, it is named as brown adipose tissue (BAT) and beige adipose tissue (beige AT). While BAT is usually observed in the interscapular region and kidney and originated from $\mathrm{Myf5}^{+} / \mathrm{PAX}^{+}$precursors, beige AT is occurred in subcutaneous adipose tissue under cold or beta-adrenergic stimuli and originated from $\mathrm{PDGFRa}^{+} / \mathrm{SCAl}^{+}$precursors by de novo differentiation or white adipocyte by transdifferentiation. BAT and beige AT also secrete proteins called batokines, which stimulate and enhance their thermogenic activity through regulation of thermogenic program, immune system, vascularization, and substrate utilization [21].

The pattern of adipokines expression reflects adipose tissue condition or even whole-body energy homeostasis status. The changes in adipokines expression caused by external stimuli or during the development of obesity and T2DM can be a potential marker to explain adipose tissue dysfunction and pathogenic status.

3.2. Adipose Tissue and Immunocytes. In obese humans and animals, the number of macrophages greatly increases within the adipose tissue to develop systematic inflammation and insulin resistance $[22,23]$. In an individual with normal body weight, the building blocks of adipose tissue include adipocytes, M2 macrophages, CD4+ T cells, and blood vessels; in the adipocytes, anti-inflammatory adipokines such as adiponectin and secreted frizzled-related protein 5 (SFRP5) are preferentially induced, and both vascular function and metabolic regulation remain normal. However, as obesity develops, the size of adipocytes increases; inflammation increases as M1 macrophages and $\mathrm{CD} 8+\mathrm{T}$ cells spread further and appropriate metabolic regulation becomes challenging. When obesity becomes intractable, it causes comprehensive metabolic dysfunction, during which the following occurs in adipose tissue: adipocytes grow larger; some adipocytes become necrotic; the increased M1 macrophages surround dead adipocytes to form a crown-like structure; the enlarged adipocytes preferentially induce proinflammatory adipokines, including leptin, tumor necrosis factor (TNF), resistin, interleukin (IL)-6, IL-18, retinol-binding protein 4 (RBP4), lipocalin-2, angiopoietin-related protein 2 (ANGPTL-2), C-C motif chemokine ligand 2 (CCL-2), C-X-C motif chemokine 5 (CXCL5), and nicotinamide phosphoribosyl transferase (NAMPT), to cause chronic inflammation and decrease blood circulation to obstruct blood flow $[24,25]$.

3.3. Proinflammatory Adipokines. Leptin is known to regulate the eating behavior via the central nervous system. In leptin-deficient mice (ob/ob mice), bulimia, obesity, and insulin resistance have been documented; these effects were reversed following a leptin injection. However, despite the increased blood leptin concentrations in obese individuals compared to normal subjects, an insufficient anorectic reaction was observed, which could be interpreted as 'leptin resistance' [26]. Furthermore, leptin increases the production of TNF and IL- 6 and promotes the production of CCL-3, CCL-4, and CCL-5, which act as proinflammatory adipokines [27, 28].

In mice, resistin impacts glucose metabolism by blocking insulin signals in adipose tissue [29]; however, its role in glucose metabolism in humans remains unclear [30, 31]. Resistin is synthesized in adipose tissue in mice [32], whereas in humans, it is synthesized primarily in 
macrophages and monocytes [33]. Resistin synthesized in human monocytes promotes the expression of TNF and IL-6 [34] and inhibits anti-inflammatory reactions of adiponectin in vascular endothelial cells $[35,36]$.

$\mathrm{RBP} 4$ is released by liver cells and transports retinol (vitamin A) throughout the body [37]. Additionally, it is also released by adipose tissue [38] and macrophages [39]. In humans, increased serum RBP4 concentrations increase blood pressure, total cholesterol, neutral fat concentration, and BMI but decrease the high-density lipoprotein (HLD) concentration [40].

Lipocalin 2 (neutrophil gelatinase-associated lipocalin and $24 \mathrm{p} 3$ ) is found in large quantities in adipose tissue $[41,42]$ and induces an inflammatory response by activating nuclear factor $-\kappa \mathrm{B}(\mathrm{NF}-\kappa \mathrm{B})[43]$.

ANGPTL2 is a circulating glycoprotein belonging to the angiopoietin-like protein family, which is abundantly expressed in the adipose tissue, lung, kidney, and skeletal muscle. Its circulating levels closely correlate with inflammation and insulin resistance. In obese mice, a decrease in ANGPTL2 attenuated the inflammatory responses and improved insulin resistance. Conversely, increased ANGPTL2 promoted inflammation in adipose tissue and insulin resistance [44].

TNF, a cytokine synthesized mainly by monocytes and macrophages, is known to play an important role in inflammatory responses and autoimmune diseases [45]. Furthermore, TNF is a core substance in the expression of obesity-related insulin resistance, as it promotes insulin resistance by reducing the tyrosine phosphorylation of insulin receptors in muscular and adipose tissues [46].

IL-6 is a proinflammatory cytokine involved in obesity and insulin resistance. In clinical trials, IL-6 has demonstrated a proportional relationship with weight $[47,48]$.

3.4. Anti-Inflammatory Adipokines. Adiponectin, an antiinflammatory protein hormone, is synthesized only by adipose tissues [16], with serum and adipose tissue levels reportedly lower in obese individuals compared to normal subjects [49]. Among the aforementioned proinflammatory adipokines, TNF and IL-6 interfere with adiponectin synthesis in the adipose tissue [50].

Adiponectin plays an important role in preventing metabolic dysfunctions. In particular, in the body, adiponectin is closely related to the functions of insulin. In an experimental study, when adiponectin was injected into diabetic mice, the efficacy of insulin improved, lowering blood glucose levels [17]. Notably, when $5^{\prime}$ adenosine monophosphate-activated protein kinase (AMPK) is activated, glucose reuptake increases in muscular tissues and gluconeogenesis decreases in the liver. Hence, it appears that insulin functions improve as adiponectin activates AMPK $[51,52]$.

Additionally, adiponectin inhibits the synthesis of proinflammatory cytokines to prevent metabolic dysfunctions. In patients with obesity or diabetes, the adiponectin concentration in the body was inversely related to the C-reactive protein (CRP) concentration; this was also observed in healthy patients presenting no obesity or diabetes
[53]. In serum and adipose tissue, TNF concentrations increased in adiponectin-deficient mice but recovered to normal following the administration of adiponectin [54].

As the adiponectin concentration decreases, the risk of cardiovascular diseases [55], high blood pressure [56], left ventricular hypertrophy [57], and myocardial infarction [58] increases. This is because adiponectin inhibits the expression of TNF and reduces the expression of vascular endothelial cell adhesion molecules (VCAM1), which ultimately leads to a decrease in monocyte adhesion [59-61].

SFRP5 is an anti-inflammatory cytokine that helps improve metabolic dysfunctions, as it prevents the binding of Wnt proteins to receptors. Wnt proteins are closely related to various inflammatory diseases and are primarily expressed in adipose tissue of obese mice. Furthermore, as the degree of obesity increases, the ratio of Wnt5 to SFRP increases. Conversely, SFRP5 is largely observed in the white adipose tissue of healthy mice; it is decreased in adipose tissue of obese mice [62].

\section{Acupuncture, Herbs, and Adipokines}

Traditional Korean medicine is a medical system that has been extensively practiced in Asia, including in China, originating over 2000 years ago, to diagnose, treat, and prevent diseases. In terms of the perspective of traditional Korean medicine, a person is healthy when the yin and yang of the body are balanced but becomes ill when these are imbalanced [63]. Furthermore, the so-called life force energy (qi) and meridians constantly circulate to facilitate the appropriate functioning of body organs, maintaining the body in a stable state. Therefore, when a problem exists in the generation or distribution of life force energy and meridians, body organ functions cannot be adequately maintained, and an individual could develop a disease [64].

In traditional Korean medicine, the causes of obesity include weakened spleen or stomach functions, abnormal body fluid accumulation, insufficient life force energy in the whole body, and the consumption of greasy high-calorific foods. When multiple organ functions are imbalanced, body wastes can excessively accumulate. Particularly, a loss of function of the spleen, lungs, and kidneys, which accumulate abnormal body fluids and wastes, is regarded as the main cause of obesity [65]. To appropriately regulate organ functions, various treatment tools of traditional Korean medicine, such as acupuncture and herbs, are applied. Here, we aimed to comprehensively understand how these treatments influence metabolic disorders and the composition of adipokines (Table 1-4).

4.1. Acupuncture. Acupuncture is a medical tool in traditional Korean medicine that prevents, mitigates, and treats diseases by stimulating a certain body surface area to evoke a specific response based on the fundamental theories of the organ function matched meridian system [93].

Electroacupuncture combines acupuncture and electrical stimulation to induce a stronger stimulation. It is often used in obesity treatment for its ability to adjust voltage and 
TABle 1: The summary of acupuncture studies on the changes of metabolic index (animal experiments).

\begin{tabular}{|c|c|c|c|c|c|c|}
\hline Intervention & Acupoints & Period & $\begin{array}{c}\text { Total } \\
\text { sessions }\end{array}$ & Model & Results & References \\
\hline $\begin{array}{l}\text { Electroacupuncture }(10 \mathrm{~Hz}, \\
15 \mathrm{~mA})\end{array}$ & CV4 and CV12 & $\begin{array}{c}\text { For } 30 \text { min on } \\
\text { alternative } \\
\text { weekdays over } 2 \\
\text { weeks }\end{array}$ & 6 & $\begin{array}{l}\text { Male obese } \\
\text { Zucker fatty } \\
\text { rat }\end{array}$ & TNF-a $\downarrow$ and body weight $\downarrow$ & $\begin{array}{l}\text { Liaw and } \\
\text { Peplow [66] }\end{array}$ \\
\hline $\begin{array}{l}\text { Electroacupuncture }(10 \mathrm{~Hz}, \\
15 \mathrm{~mA})\end{array}$ & CV4 and CV12 & $\begin{array}{c}\text { On alternate } \\
\text { weekdays over } 2 \\
\text { weeks }\end{array}$ & 6 & $\begin{array}{l}\text { Male long } \\
\text { Evans rat }\end{array}$ & $\begin{array}{c}\text { Serum IL-10 } \uparrow \text {, adipose tissue } \\
\text { adiponectin : leptin ratio } \uparrow \text {, and } \\
\text { adipose tissue IL- } 0 \uparrow\end{array}$ & $\begin{array}{c}\text { Liaw and } \\
\text { Peplow [67] }\end{array}$ \\
\hline $\begin{array}{l}\text { Electrical or manual } \\
\text { acupuncture }\end{array}$ & $\begin{array}{l}\text { Abdominal and } \\
\text { hind limb } \\
\text { muscle }\end{array}$ & $\begin{array}{l}5 \text { times/wk for } 4- \\
5 \text { wks }\end{array}$ & $20-25$ & $\begin{array}{l}\text { Female } \\
\text { pups }\end{array}$ & $\begin{array}{c}\text { Body weight } \downarrow \text {, inguinal fat } \\
\text { depot weight } \downarrow \text {, and soleus } \\
\text { muscle weight } \uparrow\end{array}$ & $\begin{array}{l}\text { Johansson } \\
\text { et al. [68] }\end{array}$ \\
\hline $\begin{array}{l}\text { Electroacupuncture }(10 \mathrm{~Hz}, \\
15 \mathrm{~mA})\end{array}$ & CV4 and CV12 & $\begin{array}{c}\text { On alternate } \\
\text { weekdays over } 2 \\
\text { weeks }\end{array}$ & 6 & $\begin{array}{c}\text { Male } \\
\text { Zucker fa/fa } \\
\text { rat }\end{array}$ & $\begin{array}{c}\text { TNF-a } \downarrow \text {, adiponectin } \uparrow \text {, } \\
\text { adiponectin : leptin ratio } \uparrow \text {, and } \\
\text { blood glucose } \downarrow\end{array}$ & $\begin{array}{l}\text { Liaw and } \\
\text { Peplow [69] }\end{array}$ \\
\hline $\begin{array}{l}\text { Electroacupuncture }(10 \mathrm{~Hz}, \\
15 \mathrm{~mA})\end{array}$ & CV4 and CV12 & For $30 \mathrm{~min}$ & 5 & $\begin{array}{l}\text { Obese male } \\
\text { ZDF rats }\end{array}$ & Blood glucose $\downarrow$ & $\begin{array}{l}\text { P.V. Peplow } \\
\text { et al }[70]\end{array}$ \\
\hline $\begin{array}{l}\text { Electroacupuncture }(10 \mathrm{~Hz}, \\
15 \mathrm{~mA})\end{array}$ & CV4 and CV12 & For $30 \mathrm{~min}$ & 6 & $\begin{array}{l}\text { Obese male } \\
\text { ZDF rats }\end{array}$ & $\begin{array}{c}\text { leptin } \downarrow \text {, adiponectin : leptin } \\
\text { ratio } \uparrow \text {, and white adipose } \\
\text { tissue } \downarrow\end{array}$ & $\begin{array}{l}\text { P.V. Peplow } \\
\text { et al [71] }\end{array}$ \\
\hline $\begin{array}{l}\text { Catgut embedding } \\
\text { acupuncture }\end{array}$ & ST36 and ST44 & $\begin{array}{l}\text { Once a week for } 4 \\
\text { weeks }\end{array}$ & 4 & $\begin{array}{c}\text { Male } \\
\text { Sprague- } \\
\text { Dawley rats }\end{array}$ & $\begin{array}{l}\text { Serum leptin } \downarrow \text {, body weight } \downarrow \text {, } \\
\text { and serum insulin level } \downarrow\end{array}$ & $\begin{array}{l}\text { Yan et al. } \\
\text { [72] }\end{array}$ \\
\hline $\begin{array}{l}\text { Pharmacopuncture } \\
\text { (Hagocho, Gamgook, and } \\
\text { Galgeun) }\end{array}$ & LI11 and ST36 & $\begin{array}{l}\text { Every other day } \\
\text { for } 4 \text { weeks }\end{array}$ & 14 & $\begin{array}{l}\text { Male obese } \\
\text { rat }\end{array}$ & $\begin{array}{c}\text { TNF-a } \downarrow \text {, IL- } 6 \downarrow \text {, leptin } \downarrow \text { plasma } \\
\text { glucose } \downarrow \text {, total cholesterol } \downarrow \text {, } \\
\text { FFA } \downarrow \text {, triglyceride } \downarrow, \text { LDL } \downarrow \text {, } \\
\text { and HDL } \uparrow\end{array}$ & $\begin{array}{l}\text { Jang et al. } \\
\text { [73] }\end{array}$ \\
\hline $\begin{array}{l}\text { Pharmacopuncture (wild } \\
\text { ginseng complex) }\end{array}$ & BL20 & $\begin{array}{l}\text { Every day during } 6 \\
\text { weeks }\end{array}$ & 42 & $\begin{array}{l}\text { Male obese } \\
\text { rat }\end{array}$ & $\begin{array}{c}\text { leptin } \downarrow \text {, adiponectin } \uparrow \text {, body } \\
\text { weight } \downarrow, \text { NF-kB } \downarrow \text {, total } \\
\text { cholesterol } \downarrow, \mathrm{LDL} \downarrow, \text { HDL } \uparrow\end{array}$ & $\begin{array}{l}\text { Kim et al. } \\
{[74]}\end{array}$ \\
\hline $\begin{array}{l}\text { Pharmacopuncture } \\
\text { (Phaseoli semen rubra) }\end{array}$ & $\begin{array}{l}\text { ST36, SI11, and } \\
\text { SP6 }\end{array}$ & $\begin{array}{l}\text { Every other day } \\
\text { for } 4 \text { weeks }\end{array}$ & 14 & $\begin{array}{l}\text { Male obese } \\
\text { rat }\end{array}$ & $\begin{array}{c}\text { leptin } \downarrow \text { and no significant } \\
\text { difference in TNF-a }\end{array}$ & Ji et al. [75] \\
\hline
\end{tabular}

TABLE 2: The summary of acupuncture studies on the changes of metabolic index (clinical research studies).

\begin{tabular}{|c|c|c|c|c|c|c|c|}
\hline $\begin{array}{l}\text { Study } \\
\text { design }\end{array}$ & Intervention (n) & Comparison (n) & Acupoints & Period & $\begin{array}{c}\text { Total } \\
\text { sessions }\end{array}$ & Results & References \\
\hline RCT & $\begin{array}{c}\text { Manual acupuncture } \\
(57)\end{array}$ & $\begin{array}{c}\text { No treatment } \\
(23)\end{array}$ & $\begin{array}{l}\text { LI4, LI11, ST21, } \\
\text { ST25, ST36, } \\
\text { ST40, ST44, SP6, } \\
\text { SP15, PC6, LR3, } \\
\text { CV4, and CV12 }\end{array}$ & $\begin{array}{l}\text { For } 30 \mathrm{~min} \text {, } \\
\text { twice weekly } \\
\text { for a month }\end{array}$ & 6 & $\begin{array}{c}\text { TNF-a } \downarrow \text {, IL- } 6 \downarrow \text {, hsCRP } \downarrow \\
\text { total cholesterol } \downarrow \text {, } \\
\text { triglyceride } \downarrow \text {, and fasting } \\
\text { blood glucose } \downarrow\end{array}$ & $\begin{array}{l}\text { Ismail et al. } \\
\text { [76] }\end{array}$ \\
\hline RCT & $\begin{array}{c}\text { Manual acupuncture } \\
(20)\end{array}$ & $\begin{array}{c}\text { Sham } \\
\text { acupuncture (20) }\end{array}$ & $\begin{array}{l}\text { LI4, HT7, ST36, } \\
\text { ST44, and SP6 }\end{array}$ & $\begin{array}{l}2 \text { sessions of } \\
20 \mathrm{~min} / \text { week }\end{array}$ & 10 & $\begin{array}{c}\text { leptin } \downarrow \text {, insulin } \downarrow \text {, body } \\
\text { weight } \downarrow \text {, ghrelin } \uparrow \text {, and } \\
\text { CCK } \uparrow\end{array}$ & $\begin{array}{l}\text { Güçel et al. } \\
\text { [77] }\end{array}$ \\
\hline RCT & $\begin{array}{l}\text { Electroacupuncture, } \\
15 \mathrm{~Hz}, 10 \mathrm{~mA} \mathrm{(19)}\end{array}$ & $\begin{array}{l}\text { Metformin } \\
\text { monotherapy } \\
\text { (20) }\end{array}$ & $\begin{array}{c}\text { ST25, SP15, } \\
\text { ST28, CV4, and } \\
\text { CV12 }\end{array}$ & $\begin{array}{l}\text { For } 30 \text { min on } \\
\text { every other } \\
\text { day over } 3 \\
\text { weeks }\end{array}$ & 10 & $\begin{array}{c}\text { leptin } \downarrow \text {, resistin } \downarrow \text {, GLP- } 1 \downarrow \text {, } \\
\text { adiponectin } \uparrow \text {, serotonin } \uparrow \text {, } \\
\text { body weight } \downarrow \text {, body mass } \\
\text { index (BMI) } \downarrow \text {, fasting } \\
\text { blood sugar (FBS) } \downarrow \text {, } \\
\text { HOMA index } \downarrow \text {, FFAs } \downarrow \text {, } \\
\text { triglyceride } \downarrow \text {, LDL } \downarrow \text {, and } \\
\text { HDL } \uparrow\end{array}$ & $\begin{array}{l}\text { Firouzjaei } \\
\text { et al. [78] }\end{array}$ \\
\hline RCT & $\begin{array}{l}\text { Catgut embedding } \\
\text { acupuncture (18) }\end{array}$ & $\begin{array}{l}\text { Sham (placebo) } \\
\text { embedding } \\
\text { acupuncture (18) }\end{array}$ & $\begin{array}{l}\text { CV6, CV12, } \\
\text { ST25, and SP6 }\end{array}$ & $\begin{array}{l}2 \text { weeks } \\
\text { interval } \\
\text { between } \\
\text { procedures }\end{array}$ & 2 & $\begin{array}{c}\text { IL- } 6 \downarrow \text {, serum glucose } \downarrow \text {, } \\
\text { total cholesterol } \downarrow \text {, FFAs } \downarrow \text {, } \\
\text { triglyceride } \downarrow \text {, LDL } \downarrow \text {, and } \\
\text { HDL } \uparrow\end{array}$ & $\begin{array}{l}\text { Tjan et al. } \\
{[79]}\end{array}$ \\
\hline
\end{tabular}


TABLE 3: The summary of herbal medicine studies on the changes of metabolic index (animal experiments).

\begin{tabular}{|c|c|c|c|c|}
\hline Intervention & Model & Duration & Results & References \\
\hline \multicolumn{5}{|l|}{ Single herbal material } \\
\hline $\begin{array}{l}\text { Rhus verniciflua leaf } \\
\text { extract }\end{array}$ & $\begin{array}{l}\text { Six-week-old male } \\
\text { C57BL/6J mice }\end{array}$ & 56 days & Leptin $\downarrow$, body weight $\downarrow$, and intraabdominal fat $\downarrow$ & $\begin{array}{l}\text { Suruga et al. } \\
\quad[80]\end{array}$ \\
\hline $\begin{array}{l}\text { Cirsium japonicum } \\
\text { DC }\end{array}$ & $\begin{array}{l}\text { Male Sprague- } \\
\text { Dawley rats }\end{array}$ & 3 weeks & $\begin{array}{c}\text { Adiponectin } \uparrow \text {, body weight } \downarrow \text {, plasma glucose } \downarrow \text {, and plasma } \\
\text { triglyceride } \downarrow\end{array}$ & Liao et a.l [81] \\
\hline \multicolumn{5}{|l|}{ Herbal formula } \\
\hline Bofu-tsusho-san & Male KKAy mice & 8 weeks & $\begin{array}{c}\text { Adiponectin } \uparrow \text {, body weight } \downarrow \text {, food intake } \downarrow \text {, LDL } \downarrow \text {, and systolic } \\
\text { blood pressure } \downarrow\end{array}$ & $\begin{array}{l}\text { Azushima } \\
\text { et al. [82] }\end{array}$ \\
\hline Bofu-tsusho-san & $\begin{array}{l}\text { The } \mathrm{C} 57 \mathrm{BL} / 6 \mathrm{~J} \\
\text { mice }\end{array}$ & 12 weeks & $\begin{array}{c}\text { Leptin } \downarrow \text {, visceral fat mass } \downarrow \text {, hepatic triacylglycerol content } \downarrow \text {, and } \\
\text { blood glucose level } \downarrow\end{array}$ & Lin et al. [83] \\
\hline Bofu-tsusho-san & $\begin{array}{l}\text { Male } \mathrm{KK} / \mathrm{Ta} \mathrm{Jcl} \\
\text { mice }\end{array}$ & 4 weeks & Adiponectin $\uparrow$ and weight of WAT $\downarrow$ & $\begin{array}{l}\text { Akagiri et al. } \\
{[84]}\end{array}$ \\
\hline Bofu-tsusho-san & Male ICR mice & 25 days & $\begin{array}{c}\text { Leptin } \downarrow \text {, adiponectin } \uparrow \text { body weight } \downarrow \text {, total fat mass } \downarrow \text {, visceral fat } \\
\text { mass } \downarrow \text {, ratio of fat mass to body weight } \downarrow \text {, and epididymal } \\
\text { adipocyte size } \downarrow\end{array}$ & $\begin{array}{l}\text { Kobayashi } \\
\text { et al. }[85]\end{array}$ \\
\hline Daesiho-tang & $\begin{array}{l}\text { Male } \mathrm{C} 57 \mathrm{BL} / 6 \\
\text { mice }\end{array}$ & 12 weeks & $\begin{array}{c}\text { Leptin } \downarrow \text {, adiponectin } \uparrow \text { body weight } \downarrow \text {, total body fat } \downarrow \text {, total } \\
\text { cholesterol } \downarrow \text {, and triglyceride } \downarrow\end{array}$ & $\begin{array}{l}\text { Hussain et al. } \\
{[86]}\end{array}$ \\
\hline $\begin{array}{l}\text { Chowiseungcheng- } \\
\text { tang }\end{array}$ & C57BL/6J mice & 12 weeks & $\begin{array}{c}\text { RBP- } 4 \downarrow \text {, adiponectin } \uparrow \text { body weight } \downarrow \text {, food efficiency ratio } \downarrow \text {, liver } \\
\text { weight } \downarrow \text {, and total VAT weight } \downarrow\end{array}$ & $\begin{array}{l}\text { Ansari et al. } \\
\text { [87] }\end{array}$ \\
\hline $\begin{array}{l}\text { Yangkyuksanwha- } \\
\text { tang }\end{array}$ & $\begin{array}{l}\text { Male } \mathrm{C} 57 \mathrm{bl} / 6 \mathrm{~J} \\
\text { mice }\end{array}$ & 6 weeks & $\begin{array}{l}\text { Leptin } \downarrow \text {, adiponectin } \uparrow \text { body weight } \downarrow \text {, glucose } \downarrow \text {, total } \\
\text { cholesterol } \downarrow \text {, triglyceride } \downarrow \text {, LDL } \downarrow \text {, and HDL } \uparrow\end{array}$ & Koh et al. [88] \\
\hline Dohaekseunggi-tang & $\begin{array}{l}\text { Male } \mathrm{C} 57 \mathrm{BL} / 6 \mathrm{~J} \\
\text { mice }\end{array}$ & 7 weeks & $\begin{array}{l}\text { Leptin } \downarrow \text {, adiponectin } \uparrow \text { body weight } \downarrow \text {, liver and adipose tissue } \\
\text { mass } \downarrow \text {, adipocyte size } \downarrow \text {, blood pressure } \downarrow \text {, total cholesterol } \downarrow \text {, } \\
\text { triglyceride } \downarrow \text {, glucose } \downarrow \text {, LDL } \downarrow \text {, and HDL } \uparrow\end{array}$ & Sung et al. [89] \\
\hline Taeeumjowui-tang & C57BL/6J mice & 12 weeks & $\begin{array}{l}\text { Leptin } \downarrow \text {, resistin } \downarrow \text {, PAI- } 1 \downarrow \text {, adiponectin } \uparrow \text { body weight } \downarrow \text {, food } \\
\text { efficiency ratio } \downarrow \text {, plasma total cholesterol } \downarrow \text {, the hepatic fatty acid, } \\
\text { and triglyceride and cholesterol contents } \downarrow\end{array}$ & Choi et al. [90] \\
\hline $\begin{array}{l}\text { Tongqiaohuoxue } \\
\text { decoction }\end{array}$ & $\begin{array}{l}\text { Male C57BL/6 } \\
\text { mice }\end{array}$ & 4 weeks & $\begin{array}{c}\text { Adiponectin } \uparrow \text {, leptin } \downarrow \text {, PAI- } 1 \downarrow \text {, blood glucose } \downarrow \text {, total } \\
\text { cholesterol } \downarrow \text {, and triglyceride } \downarrow\end{array}$ & Kim et al. [91] \\
\hline
\end{tabular}

TABLE 4: The summary of herbal medicine studies on the changes of metabolic index (clinical research studies).

\begin{tabular}{|c|c|c|c|c|c|}
\hline $\begin{array}{l}\text { Study } \\
\text { design }\end{array}$ & Intervention (n) & Comparison (n) & Duration & Results & References \\
\hline RCT & $\begin{array}{c}\text { Bofu-tsusho-san } \\
\text { (54) }\end{array}$ & $\begin{array}{l}\text { Conventional control } \\
\text { therapy (52) }\end{array}$ & 24 weeks & $\begin{array}{c}\text { Resistin } \uparrow \text {, body weight } \downarrow \text {, body mass index (BMI) } \\
\downarrow \text {, and systolic blood pressure } \downarrow\end{array}$ & $\begin{array}{c}\text { Azushima et al. } \\
\text { [92] }\end{array}$ \\
\hline
\end{tabular}

maintain a constant frequency [4]. According to a recent study [94], electroacupuncture treatment was effective in weight control and improved the levels of various blood lipids. Furthermore, it has gained attention as a treatment that can be used for the prevention and treatment of obesityrelated metabolic syndromes.

Catgut embedding therapy treats a disease by inserting a foreign substance into an acupuncture point or an affected area, providing constant stimulation to the acupuncture point. The advantages include stimulation of a treatment area and maximization of stimulus via long needle-retention time. Recently, it has been widely used in oriental plastic surgery, skincare, and obesity [95].

Pharmacopuncture combines acupuncture and pharmacological therapies, which can stimulate meridian points, producing characteristic drug effects by simultaneously injecting the purified herbal medicine extract into an acupuncture point [96].

4.1.1. Manual Acupuncture. A randomized, controlled trial confirmed that the significant reduction of TNF- $\alpha$, IL- 6 , and hsCRP in obese patients treated with acupuncture (LI4, LI11, ST21, ST25, ST36, ST40, ST44, SP6, SP15, PC6, LR3, CV4, and CV12, bilaterally, two sessions of 30 minutes/week for six months) [76].

Forty women with a body mass index over 30 were equally randomized to either an acupuncture group or a sham (nonpenetrating) acupuncture group and received treatment at LI4, HT7, ST36, ST44, and SP6 bilaterally. Both groups had two sessions of $20 \mathrm{~min} /$ week for a total of 10 sessions. In this study, acupuncture showed its effect on 
weight loss and its ability to decrease serum insulin and leptin levels and to increase ghrelin and CCK levels [77].

\subsubsection{Electroacupuncture}

(1). Animal Experiment. According to Liaw and Peplow [66], in obese Zucker mice receiving electroacupuncture treatment at $10 \mathrm{~Hz}$ (at CV12 and CV4 acupoints for a total of six treatments every other day over two weeks; $0.25 \mathrm{~mm} \times 15 \mathrm{~mm}$ in size; electroacupuncture performed for $30 \mathrm{~min}$ ), the serum TNF-a level was significantly lower than that in untreated mice. However, no significant difference was observed between the two mice groups in the serum leptin, adiponectin, and IL-10 levels. The mean body weight on the first day and last day was decreased in both EA treated group and untreated group. These results are presumed to be the effects of long-term exposure to the anesthetic gas. In the EA treatment group, blood glucose levels in the first and second weeks were similar, whereas in the untreated group, the blood glucose levels were increased in the second week. Therefore, it can be seen that the treatment of EA does not cause hyperglycemia. They also identified that EA increased the serum IL-10 level, the adiponectin : leptin ratio, and IL10 level in adipose tissue of lean rats [67].

Johansson et al. [68] showed that repeated electrical stimulation regulated key functional molecular pathways important for insulin sensitivity in soleus muscle and mesenteric adipose tissue of DHT-induced PCOS rats. Also, repeated applications of EA were seen to have had a significant differential effect for serum tumor necrosis factor-a, adiponectin, the adiponectin:leptin ratio, and blood glucose in both obese Zucker fatty rats and high-fat diet-induced obese Long Evans rats [69].

Peplow investigated the effect of electroacupuncture at the CV12 and CV4 acupoints in male obese Zucker diabetic rats with different aged mice of 12 13 weeks and 21 24 weeks. In young ages, adiponectin and leptin in blood serum and white adipose tissue decreased, while in old ages, no significant differences were noted between the groups in serum insulin, glucose, insulin-to-glucose ratio, adiponectin, leptin, adiponectin-to-leptin ratio, and white adipose tissue $[70,71]$.

(2). Clinical Research. Firouzjaei et al. [78] performed a randomized clinical trial (RCT) to examine the differences in indices such as weight loss and insulin sensitivity between metformin monotherapy and a combined therapy of metformin and acupuncture in overweight/obese patients with type 2 diabetes. In total, 39 patients were recruited: 19 subjects in the case group received metformin and acupuncture and 20 subjects in the control group received metformin and sham acupuncture. Electroacupuncture was performed 10 times, each of which lasted for $30 \mathrm{~min}$, every other day for a total duration of 3 weeks. Electropuncture was performed with a frequency of $15 \mathrm{~Hz} / 10 \mathrm{~mA}$ and a needle size of $0.25 \mathrm{~mm} \times 0.40 \mathrm{~mm} / 32$ Gauge (EACU brand, Maanshan, Anhui, China), applied to a total of eight points: ST 25, SP 15, ST 28, CV 12, and CV 6. Additionally, ear acupuncture was performed at the following points: Sanjiao,
Jidian (hunger), Wei (stomach), Shenmen, Neifenmi (endocrine), and Pi (spleen). In the control group, the needles were inserted superficially at nonacupuncture points in the abdomen, with electric lines connected. For auricular acupuncture, sticky layers without seeds were used in the sham acupuncture therapy. Compared to the control group, in the case group receiving acupuncture and metformin, indices such as body weight, BMI, fasting blood sugar, and the homeostatic model assessment (HOMA) index improved significantly, but serum leptin, resistin, and glucagon-like peptide 1(GLP-1) decreased, and adiponectin and serotonin significantly increased. These results demonstrated that a combination therapy of metformin and acupuncture is effective in anti-inflammatory responses, adipokine improvements, and body weight loss.

\subsubsection{Catgut Embedding Acupuncture}

(1) Animal Experiment. In the study of Yan et al., catgut embedding at points ST 36 and ST 44 promoted weight loss and decreased serum leptin and insulin levels in response to four sessions [72].

(2) Clinical Research. Tjan et al. [79] conducted a double blind, randomized, placebo-controlled trial in which 36 obese patients were treated with a combination therapy of dietary intervention and catgut embedding acupuncture, examining the effects of the combination therapy on IL-6 and the BMI. The patients were randomly allocated into two groups, receiving either catgut embedding acupuncture (treatment group) or sham embedding acupuncture (placebo control group). Both groups underwent identical dietary intervention. Overall, two catgut embedding acupuncture sessions were performed over two weeks at the following acupuncture points: CV12, ST25, CV6, and SP6. In the treatment group, IL-6 and BMI decreased. The difference in the average BMI decreased between the two groups and was recorded as 0.34 . Regarding the reduced IL-6 levels, no significant difference was observed between the two groups. These results demonstrate that catgut embedding acupuncture lowers IL-6 levels and helps improve BMI in obese patients with diet intervention.

4.1.4. Pharmacopuncture. Nam et al. [97] analyzed clinical and animal experimental research to examine the effects of pharmacopuncture on obesity treatment. Analysis of animal experimental research reported the antiobesity mechanism of pharmacopuncture by documenting the effects of pharmacopuncture on protein concentrations, including TNF-a, IL-6, leptin, and adiponectin. The evaluation of clinical research outlined the relationships between pharmacopuncture and measures such as body weight, waist circumference, and BMI. However, it still remains to investigate the relationship between pharmacopuncture and adipokine in clinical research.

(1) Animal Experiments. Jang et al. [73] inserted $0.2 \mathrm{~mL}$ of Hagocho (Prunella vulgaris L.), Gamgook (Chrysanthemum 
indicum L.), and Galgeun (Puerariae radix) at LI11 and ST36, every other day for four weeks, to examine their antiobesity effects. The results demonstrated that Hagocho, Gamgook, and Galgeun decreased the serum concentrations of TNF-a, IL-6, and leptin, plasma glucose, and total cholesterol.

Kim et al. [74] injected wild ginseng complex (WGC), composed of Panax quinquefolius (Ginseng Radix Alba: wild American ginseng), Bos taurus Linné var. domesticus (Bovis Calculus, ox bezoar), Ursus arctos Linné (Fel Ursi, gall bladder of a bear), and Ondatra zibethicus (Moschus, musk), into obese mice to examine their antiobesity effects. WGC was injected into the left and right sides of an area that corresponds to BL20 of humans. A dose of $0.2 \mathrm{~mL}$ was injected once a day. In the control group, WGC was substituted with physiological saline. The results demonstrated that the WGC injection interfered with the NF- $\kappa \mathrm{B}$ expression, which could have inhibited further inflammatory responses. Additionally, in the WGC treatment group, the concentrations of total cholesterol, LDL-cholesterol, and natural fats decreased significantly; the levels of HDLcholesterol significantly increased; leptin release decreased; and adiponectin expression was enhanced.

Ji et al. [75] injected $0.7 \mathrm{~mL}$ Phaseoli semen into rats at locations corresponding to human ST36, LI11, and SP6, every other day for four weeks, demonstrating that Phaseoli semen treatment decreased total cholesterol, neutral fats, LDL-cholesterol, TNF-a, and leptin but increased HDLcholesterol.

\subsection{Herbal Medicine}

4.2.1. Single Herbal Material. Suruga et al. [80] injected a Rhus verniciflua leaf extract to high-fat diet-induced obese mice to demonstrate its antiobesity effects. In mice injected with the extract, the rate of weight gain was reduced when compared with the control group mice. Additionally, visceral fat in the abdomen and the serum leptin concentration decreased significantly.

Liao et al. [81] reported that the plasma adiponectin level was greatly increased in diabetic rats treated with Cirsium japonicum DC, while no obvious effect of the flavones on the dysregulated plasma insulin level and expressions of leptin and glucose transporter 4 (GLUT4) was observed.

\subsubsection{Herbal Formula}

(1) Animal Experiments. Among the various formulas, several studies have evaluated Bofutsushosan (BOF) (Table 5) [82-85, 92]. Azushima et al. [82] conducted mice experiments to evaluate the mechanisms through which BOF improves different metabolic disorders accompanying obesity. In obese mice injected with BOF, body weight, food intake, LDL-cholesterol, and systolic blood pressure decreased; the concentrations of circulating adiponectin, adiponectin within adipose tissue and PPAR gene expression increased. Lin et al. [83] injected BOF into high-fat-fed mice for four weeks and examined the antidiabetic and antihyperlipidemic effects of BOF by evaluating the blood and musculoskeletal and other tissues. Their results showed that the BOF injection reduced blood glucose and gluconeogenesis in the liver and inhibited serum neutral fats, free fatty acids, and leptin. Akagiri et al. [84] examined the antiobesity effects of BOF in high-fat-fed mice and reported that, in BOF-injected mice, the weight of white adipose tissue was increased and adipose tissue size decreased; the adiponectin concentration in adipose tissue increased; and serum ghrelin concentration decreased. Kobayashi et al. [85] reported that injecting BOF for 25 days to mice fed a high-fat for 5 weeks decreased their body weight, visceral fat, and adipose tissue size and significantly reduced serum concentrations of glucose, insulin, leptin, and natural fats. Additionally, concentrations of adiponectin and leptin and the mRNA expression of uncoupling protein 1 (UCP1) increased in brown adipose tissue.

Hussain et al. [86] and Ansari et al. [87] reported relationships between intestinal microbiota improvement and antiobesity effects of Daesiho-Tang (DSHT) and Chowiseungcheng-tang (CST). In obese mice fed a high-fat diet and treated with DHST, body weight, body fat, total cholesterol, and neutral fat concentration decreased significantly; gene expressions of leptin and adiponectin were regulated; and additionally, intestinal microbiota beneficial to the body increased. In obese mice injected with CST, the expression levels of obesity-related genes were reduced in the hypothalamus; the expression levels of obesity-inhibiting genes were enhanced; the gene expression of an adipokine that promotes obesity, RBP-4, effectively decreased; the gene expression of adiponectin, an adipokine that inhibits obesity, significantly increased; intestinal microbiota beneficial to the body increased in the CST treatment group as observed in the DSHT experiment, Koh et al. [88] injected Yangkyuksanwha-tang (YST) to high-fat diet-induced obese mice for six weeks and reported that the body weight and levels of blood glucose, total cholesterol, neutral fats, and LDLcholesterol were decreased; HDL-cholesterol was increased; adipose tissues and weights of various organs decreased; the gene expression of leptin decreased; and the gene expression of adiponectin increased. Sung et al. [89] examined the antiobesity, antihyperlipidemic, and antihypertensive effects of Dohaekseunggi-tang (DHSGT) on high-fat diet-induced obese mice. When DHSGT was orally administered to mice, their body weight, liver and adipose tissue mass, size of adipose tissue, and blood pressure decreased when compared to the mice in the control group. DHSGT decreased serum concentrations of total cholesterol, LDL-cholesterol, neutral fats, blood glucose, and leptin, with increased HDLcholesterol and adiponectin levels observed. Choi et al. [90] examined the antiobesity effects of Taeeumjowui-tang (TJ) on high-fat diet-induced obese mice and demonstrated that the TJ injection improved insulin resistance, dyslipidemia, and hepatic cirrhosis, decreasing serum concentrations of leptin, resistin, and PAI-1 while increasing adiponectin concentration.

Kim et al. [91] examined Tongqiaohuoxue decoction with high-fat diet-induced obese mice. After treatment, proinflammatory cytokines were significantly 
TABle 5: The composition of herbal formula.

\begin{tabular}{|c|c|c|}
\hline Formula name & Pharmacognostic name of herbs & References \\
\hline Bofu-tsusho-san & $\begin{array}{l}\text { Scutellariae radix, Glycyrrhizae radix, Platycodi radix, Gypsum fibrosum, Atractyloids } \\
\text { rhizoma, Rhei rhizoma, Schizonepetae spica, Gardeniae fructus, Paeoniae radix, Cnidii } \\
\text { rhizoma, Angelicae radix, Menthae herba, Ledebouriellae radix, Ephedrae herba, } \\
\text { Forsythiae fructus, Zingiberis rhizoma, Kadinum, and Natrium sulfuricum }\end{array}$ & Azushima et al. $[82,92]$ \\
\hline Bofu-tsusho-san & $\begin{array}{c}\text { Scutellariae radix, Glycyrrhizae radix, Platycodi radix, Atractyloids lanceae rhizoma, } \\
\text { Rhei rhizoma, Schizonepetae spica, Gardeniae fructus, Paeoniae radix, Cnidii rhizoma, } \\
\text { Angelicae radix, Menthae follium, Saposhnikoviae radix, Ephedrae herba, Forsythiae } \\
\text { fructus, Zingiberis rhizoma, Gypsum fibrosum, Natrium sulfuricum, and Talcum } \\
\text { crystallinum }\end{array}$ & $\begin{array}{l}\text { Lin et al. [83], Kobayashi } \\
\text { et al. [85] }\end{array}$ \\
\hline Bofu-tsusho-san & $\begin{array}{l}\text { Scutellariae radix, Glycyrrhizae radix, Platycodi radix, Atractyloids lanceae rhizoma, } \\
\text { Rhei rhizoma, Schizonepetae spica, Gardeniae fructus, Paeoniae radix, Cnidii rhizoma, } \\
\text { Angelicae radix, Menthae follium, Saposhnikoviae radix, Ephedrae herba, Forsythiae } \\
\text { fructus, Zingiberis rhizoma, Kaolinum, Gypsum fibrosum, and Natrium sulfuricum }\end{array}$ & Akagiri et al. [84] \\
\hline Daesiho-tang & $\begin{array}{c}\text { Bupleuri radix, Pinelliae rhizome, Zingiberis rhizome, Scutellariae radix, Paeoniae } \\
\text { radix, Zizyphus fructus, Ponciri fructus, and Rhei undulati rhizome } \\
\text { Coicis semen, Castaneae semen, Raphani semen, Ephedrae herba, Platycodi radix, }\end{array}$ & Hussain et al. [86] \\
\hline Chowiseungcheng-tang & $\begin{array}{c}\text { Liriopis tuber, Schizandrae fructus, Acori graminei rhizoma, Polygalae radix, Asparagi } \\
\text { radix, Zizyphi spinosae semen, and Longanae arillus }\end{array}$ & Ansari et al. [87] \\
\hline Yangkyuksanwha-tang & $\begin{array}{c}\text { Rehmannia glutinosa, Lonicera japonica Thunberg, Forsythia viridissima Lindley, } \\
\text { Gardenia jasminoides Ellis, Mentha arvensis L. var. piperascens Malinvaud ex Holmes, } \\
\text { Anemarrhena asphodeloides Bunge, Gypsum, Saposhnikovia divaricata Schischkin, } \\
\text { and Schizonepeta tenuifolia Briquet }\end{array}$ & Koh et al. [88] \\
\hline Dohaekseunggi-tang & $\begin{array}{c}\text { Glycyrrhizae uralensis Fischer, Rheum undulatum Linne, Prunus persica Linne, } \\
\text { Cinnamomum cassia Presl, and Natrii sulfas }\end{array}$ & \multirow{2}{*}{ Sung et al. [89] } \\
\hline Dohongsamul-tang & $\begin{array}{c}\text { Angelis gigantis radix, Persicae semen, Rehmanniae radix, Cnidii rhizome, and } \\
\text { Carthami flos }\end{array}$ & \\
\hline Taeeumjowui-tang & $\begin{array}{c}\text { Coicis Semen, Castaneae Semen, Raphani Semen, Schizandrae fructus, Platycodi radix, } \\
\text { Radix Ophiopogonis, Acori Graminei Rhizoma, and Ephedrae herba }\end{array}$ & Choi et al. [90] \\
\hline $\begin{array}{l}\text { Tongqiaohuoxue } \\
\text { decoction }\end{array}$ & $\begin{array}{l}\text { Paeonia obovata Maxim, Cnidium officinale Makino, Prunus persica (Linne) Batsch, } \\
\text { Carthamus tinctorius L., Allium fistulosum L., Zizyphus jujube var. inermis (Bunge) } \\
\text { Rehder, Zingiber officinale Roscoe, and Saussurea costus (Falc.) Lipsch }\end{array}$ & Kim et al. [91] \\
\hline
\end{tabular}

downregulated in the blood, adipose tissue, and liver. Simultaneously, it significantly reduced plasminogen activator inhibitor-1 (PAI-1) levels in serum, adipose tissue, and the liver.

(2) Clinical Research. Azushima et al. [92] conducted a multicenter, randomized, open-label, parallel group controlled trial to investigate the antiobesity and antihypertensive effects of BOF in obese patients with hypertension and observed that the BOF injection decreased systolic blood pressure. Furthermore, while no significant difference was observed in the serum adiponectin concentration between the BOF-injected group and the control group, the resistin concentration increased significantly.

\section{Perspectives}

As the lifestyle and eating habits of modern humans have undergone a dramatic change, the number of obese individuals has increased across all ages. Obesity-related chronic inflammation can give rise to diseases such as type 2 diabetes, dyslipidemia, cardiovascular diseases, and cancer. For the treatment of obesity, Western medicine applies the pharmacological or surgical strategies. Regarding pharmacological treatments, side effects, including lethargy, depression, headache, dizziness, and nausea, may occur [98].
In terms of the surgical interventions used in patients with severe obesity, complications such as central venous sinus thrombosis, pulmonary embolism, pneumonia, myocardial infarction, and cholelithiasis can be followed after surgery [99]. For this reason, there is a need for a noninvasive and safer treatment options.

In the field of traditional Korean medicine, several interventions, including herbal medicine, acupuncture, electroacupuncture, pharmacopuncture, and catgut embedding acupuncture, have been used to treat and manage obesity. These treatments for obesity are to improve the condition in which energy metabolism is imbalanced, problems with the malfunction of the several organs [100]. The adipose tissue is not solely an energy storage organ, but it is also involved in metabolic actions throughout the body by releasing proteins called adipokines. As obesity progresses, proinflammatory adipokines, including leptin, TNF, resistin, IL-6, RBP4, lipocalin-2, and ANGPTL-2, are preferentially synthesized and cause chronic inflammation. Therefore, various traditional Korean medicinal treatments for patients with obesity can be expected to help decrease body weight and related systemic reactions with anti-inflammatory effects, based on which an association to adipokine actions involved in metabolism, immunity, and homeostasis can be inferred.

According to studies that examined adipokine responses to electroacupuncture, pharmacopuncture, and catgut 
embedding acupuncture, acupuncture treatments decreased TNF-a, leptin, resistin, and IL- 6 but increased adiponectin and serotonin. According to studies that examined adipokine responses to single herbal materials and herbal complexes, herbal medicines decreased TNF-a, leptin, resistin, RBP-4, and PAI-1 but increased adiponectin. Electroacupuncture treatment regulated blood glucose and insulin concentrations; catgut embedding acupuncture treatment decreased BMI; various pharmacopuncture treatments were mainly helpful in controlling the cholesterol levels. An $R$. verniciflua leaf extract decreased body weight and visceral fatty tissue; BOF controlled cholesterol levels and decreased blood pressure to express UCP-1, which helped increase the body temperature; DSHT and CST improved intestinal microbiota; YST and DHSGT decreased the size of adipocytes and adipose tissue; TJ improved insulin resistance, dyslipidemia, and hepatic cirrhosis. Traditional Korean medicine treatments that included acupuncture or herbs altered the concentration and expression of obesity-related adipokines and influenced various other indices related to obesity or metabolic diseases.

In this review, we discussed whether obesity treatments utilizing acupuncture and herbal medicine affected adipokines indicating the obesity-related inflammation in animal experiments and clinical research studies. Furthermore, we summarized the changes in adipokines induced by acupuncture or herbal interventions. We suggest that future research requires evaluating the adipokines, which are known to play an integral role in metabolic regulation, in the assessment of obesity treatments utilizing acupuncture and herbs. Moreover, we anticipate that this paper can provide useful basic information for research that aims to examine the effects of acupuncture and herbs on changes in obesityrelated inflammatory disease and that aims to search the surrogate markers from adipokines during treatments.

\section{Data Availability}

The data used to support the findings of this study are included within the article.

\section{Conflicts of Interest}

The authors declare that there are no conflicts of interest regarding the publication of this paper.

\section{Authors' Contributions}

J.-E.Y, M.-W.L., and J.-Y.K. were involved in conceptualization; S.-E.B. and M.-W.L. were involved in formal analysis; J.-Y.K. was involved in investigation; J.-E.Y, RP, and J.-Y.K were involved in writing the original draft; J.-E.Y and S.-E.B were involved in reviewing and editing; J.-E.Y and M.-W.L. were involved in supervision and funding acquisition; and J.E.Y. was involved in project administration.

\section{Acknowledgments}

This work was supported by the Regional Leading Research Center (RLRC) and Young Researchers Program through the National Research Foundation of South Korea (NRF2019R1A5A8083404 and NRF-2020R1C1C1005546).

\section{References}

[1] WHO, https://www.who.int/topics/obesity/en/.

[2] E. D. Jung, J. Lee, and H.-S. Shon, “The correlation between central obesity and glucose, lipid metabolism and macrovascular complication in elderly type 2 diabetes," The Journal of Korean Diabetes Association, vol. 31, no. 4, pp. 343-350, 2007.

[3] M. Lafontan, "Adipose tissue and adipocyte dysregulation," Diabetes \& Metabolism, vol. 40, no. 1, pp. 16-28, 2014.

[4] G. Jessica, G. Roberto, G. Carmen et al., "Effects of acupuncture on obesity and adipokines involved in body weight control," Journal of Homeopathy \& Ayurvedic Medicine, vol. 2, no. 3, pp. 1-7, 2013.

[5] A. M. Castro, L. E. Macedo-de la Concha, and C. A. PantojaMeléndez, "Low-grade inflammation and its relation to obesity and chronic degenerative diseases," Revista Médica del Hospital General de México, vol. 80, no. 2, pp. 101-105, 2017.

[6] E. Stolarczyk, "Adipose tissue inflammation in obesity: a metabolic or immune response?" Current Opinion in Pharmacology, vol. 37, pp. 35-40, 2017.

[7] B. K. Surmi and A. H. Hasty, "Macrophage infiltration into adipose tissue: initiation, propagation and remodeling," Future Lipidology, vol. 3, no. 5, pp. 545-556, 2008.

[8] T. Suganami and Y. Ogawa, "Adipose tissue macrophages: their role in adipose tissue remodeling," Journal of Leukocyte Biology, vol. 88, no. 1, pp. 33-39, 2010.

[9] P.-C. Chan and P.-S. Hsieh, "The role of adipocyte hypertrophyand hypoxia in the development of obesityssociatedadipose tissue inflammation and insulin resistance," in Adiposity-mics and Molecular Understanding, J. Gordeladze, Ed., pp. 127-141, IntechOpen Limited, London, UK, 2017.

[10] J. Jo, O. Gavrilova, S. Pack et al., "Hypertrophy and/or hyperplasia: dynamics of adipose tissue growth," PLOS Computational Biology, vol. 5, no. 3, Article ID e1000324, 2009.

[11] N. Halberg, T. Khan, M. E. Trujillo et al., "Hypoxia-inducible factor $1 \alpha$ induces fibrosis and insulin resistance in white adipose tissue," Molecular and Cellular Biology, vol. 29, no. 16, pp. 4467-4483, 2009.

[12] J. Ye, Z. Gao, J. Yin, and Q. He, "Hypoxia is a potential risk factor for chronic inflammation and adiponectin reduction in adipose tissue of ob/ob and dietary obese mice," American Journal of Physiology-Endocrinology and Metabolism, vol. 293, no. 4, pp. E1118-E1128, 2007.

[13] B. Chen, K. S. L. Lam, Y. Wang et al., "Hypoxia dysregulates the production of adiponectin and plasminogen activator inhibitor-1 independent of reactive oxygen species in adipocytes," Biochemical and Biophysical Research Communications, vol. 341, no. 2, pp. 549-556, 2006.

[14] M. S. Ellulu, I. Patimah, H. Khaza'ai, A. Rahmat, and Y. Abed, "Obesity and inflammation: the linking mechanism and the complications," Archives of Medical Science, vol. 4, no. 4, pp. 851-863, 2017.

[15] G. S. Hotamisligil, "Inflammation and metabolic disorders," Nature, vol. 444, no. 7121, pp. 860-867, 2006.

[16] N. Ouchi, S. Kihara, T. Funahashi, Y. Matsuzawa, and $\mathrm{K}$. Walsh, "Obesity, adiponectin and vascular inflammatory disease," Current Opinion in Lipidology, vol. 14, no. 6, pp. 561-566, 2003. 
[17] A. H. Berg and P. E. Scherer, "Adipose tissue, inflammation, and cardiovascular disease," Circulation Research, vol. 96, no. 9, pp. 939-949, 2005.

[18] K. Samaras, N. K. Botelho, D. J. Chisholm, and R. V. Lord, "Subcutaneous and visceral adipose tissue gene expression of serum adipokines that predict type 2 diabetes," Obesity, vol. 18, no. 5, pp. 884-889, 2010.

[19] S. K. Fried, D. A. Bunkin, and A. S. Greenberg, "Omental and subcutaneous adipose tissues of obese subjects release interleukin-6: depot difference and regulation by Glucocorticoid1," The Journal of Clinical Endocrinology \& Metabolism, vol. 83, no. 3, pp. 847-850, 1998.

[20] M. Bluher and C. S. Mantzoros, "From leptin to other adipokines in health and disease: facts and expectations at the beginning of the 21st century," Metabolism, vol. 64, no. 1, pp. 131-145, 2014.

[21] M. W. Lee, M. Lee, and K. J. Oh, “Adipose tissue-derived signatures for obesity and type 2 diabetes: adipokines, batokines and MicroRNAs," Journal of Clinical Medicine, vol. 8, no. 6, p. 854, 2019.

[22] H. Xu, G. T. Barnes, Q. Yang et al., "Chronic inflammation in fat plays a crucial role in the development of obesity-related insulin resistance," Journal of Clinical Investigation, vol. 112, no. 12 , pp. 1821-1830, 2003.

[23] S. P. Weisberg, D. McCann, M. Desai, M. Rosenbaum, R. L. Leibel, and A. W. Ferrante, "Obesity is associated with macrophage accumulation in adipose tissue," Journal of Clinical Investigation, vol. 112, no. 12, pp. 1796-1808, 2003.

[24] S. Cinti, G. Mitchell, G. Barbatelli et al., "Adipocyte death defines macrophage localization and function in adipose tissue of obese mice and humans," Journal of Lipid Research, vol. 46, no. 11, pp. 2347-2355, 2005.

[25] I. Murano, G. Barbatelli, V. Parisani et al., "Dead adipocytes, detected as crown-like structures, are prevalent in visceral fat depots of genetically obese mice," Journal of Lipid Research, vol. 49, no. 7, pp. 1562-1568, 2008.

[26] J. M. Friedman and J. L. Halaas, "Leptin and the regulation of body weight in mammals," Nature, vol. 395, no. 6704, pp. 763-770, 1998.

[27] J. Santos-Alvarez, R. Goberna, and V. Sánchez-Margalet, "Human leptin stimulates proliferation and activation of human circulating monocytes," Cellular Immunology, vol. 194, no. 1, pp. 6-11, 1999.

[28] N. Kiquchi, T. Maeda, Y. Kobayashi et al., "Leptin enhances CC-chemokine ligand expression in cultured murine macrophage," Biochem. Biophys. Res. Commun.vol. 384, no. 3, pp. 311-315, 2009.

[29] C. M. Steppan, J. Wang, E. L. Whiteman, M. J. Birnbaum, and M. A. Lazar, "Activation of SOCS-3 by resistin," Molecular and Cellular Biology, vol. 25, no. 4, pp. 1569-1575, 2005.

[30] L. K. Heilbronn, J. Rood, L. Janderova et al., "Relationship between serum resistin concentrations and insulin resistance in nonobese, obese, and obese diabetic subjects," The Journal of Clinical Endocrinology \& Metabolism, vol. 89, no. 4, pp. 1844-1848, 2004.

[31] J. H. Lee, J. L. Chan, N. Yiannakouris et al., "Circulating resistin levels are not associated with obesity or insulin resistance in humans and are not regulated by fasting or leptin administration: cross-sectional and interventional studies in normal, insulin-resistant, and diabetic subjects," The Journal of Clinical Endocrinology \& Metabolism, vol. 88, no. 10, pp. 4848-4856, 2003.
[32] C. M. Steppan, S. T. Bailey, S. Bhat et al., "The hormone resistin links obesity to diabetes," Nature, vol. 409, no. 6818 , pp. 307-312, 2001.

[33] D. B. Savage, C. P. Sewter, E. S. Klenk et al., "Resistin/Fizz3 expression in relation to obesity and peroxisome proliferator-activated receptor- action in humans," Diabetes, vol. 50, no. 10, pp. 2199-2202, 2001.

[34] M. Bokarewa, I. Nagaev, L. Dahlberg, U. Smith, and A. Tarkowski, "Resistin, an adipokine with potent proinflammatory properties," The Journal of Immunology, vol. 174, no. 9, pp. 5789-5795, 2005.

[35] S. Verma, S.-H. Li, C.-H. Wang et al., "Resistin promotes endothelial cell activation," Circulation, vol. 108, no. 6, pp. 736-740, 2003.

[36] D. Kawanami, K. Maemura, N. Takeda et al., "Direct reciprocal effects of resistin and adiponectin on vascular endothelial cells: a new insight into adipocytokine-endothelial cell interactions," Biochemical and Biophysical Research Communications, vol. 314, no. 2, pp. 415-419, 2004.

[37] L. Quadro, W. S. Blaner, D. J. Salchow et al., "Impaired retinal function and vitamin A availability in mice lacking retinol-binding protein," The EMBO Journal, vol. 18, no. 17, pp. 4633-4644, 1999.

[38] Q. Yang, T. E. Graham, N. Mody et al., "Serum retinol binding protein 4 contributes to insulin resistance in obesity and type 2 diabetes," Nature, vol. 436, no. 7049, pp. 356-362, 2005.

[39] M. Broch, R. Ramírez, M. T. Auguet et al., "Macrophages are novel sites of expression and regulation of retinol binding protein-4 (RBP4)," Physiological Research, vol. 59, no. 2, pp. 299-303, 2010.

[40] T. E. Graham, Q. Yang, M. Blüher et al., "Retinol-binding protein 4 and insulin resistance in lean, obese, and diabetic subjects," New England Journal of Medicine, vol. 354, no. 24, pp. 2552-2563, 2006.

[41] Q.-W. Yan, Q. Yang, N. Mody et al., "The adipokine lipocalin 2 is regulated by obesity and promotes insulin resistance," Diabetes, vol. 56, no. 10, pp. 2533-2540, 2007.

[42] J. Zhang, Y. Wu, Y. Zhang, D. LeRoith, D. A. Bernlohr, and $\mathrm{X}$. Chen, "The role of lipocalin 2 in the regulation of inflammation in adipocytes and macrophages," Molecular Endocrinology, vol. 22, no. 6, pp. 1416-1426, 2008.

[43] J. B. Cowland, T. Muta, and N. Borregaard, "IL-1 $\beta$-Specific up-regulation of neutrophil gelatinase-associated lipocalin is controlled by $\mathrm{I} \kappa \mathrm{B}-\zeta$," The Journal of Immunology, vol. 176, no. 9, pp. 5559-5566, 2006.

[44] M. Tabata, T. Kadomatsu, S. Fukuhara et al., "Angiopoietinlike protein 2 promotes chronic adipose tissue inflammation and obesity-related systemic insulin resistance," Cell Metabolism, vol. 10, no. 3, pp. 178-188, 2009.

[45] G. Hotamisligil, N. Shargill, and B. Spiegelman, "Adipose expression of tumor necrosis factor-alpha: direct role in obesity-linked insulin resistance," Science, vol. 259, no. 5091, pp. 87-91, 1993.

[46] G. S. Hotamisligil, A. Budavari, D. Murray, and B. M. Spiegelman, "Reduced tyrosine kinase activity of the insulin receptor in obesity-diabetes. Central role of tumor necrosis factor-alpha," Journal of Clinical Investigation, vol. 94, no. 4, pp. 1543-1549, 1994.

[47] K. Esposito, A. Pontillo, C. Di Palo et al., "Effect of weight loss and lifestyle changes on vascular inflammatory markers in obese women," JAMA, vol. 289 , no. 14 , pp. 1799-1804, 2003. 
[48] P. Ziccardi, F. Nappo, G. Giugliano et al., "Reduction of inflammatory cytokine concentrations and improvement of endothelial functions in obese women after weight loss over one year," Circulation, vol. 105, no. 7, pp. 804-809, 2002.

[49] M. Ryo, T. Nakamura, S. Kihara et al., "Adiponectin as a biomarker of the metabolic syndrome," Circulation Journal, vol. 68, no. 11, pp. 975-981, 2004.

[50] S. Li, H. J. Shin, E. L. Ding, and R. M. van Dam, "Adiponectin levels and risk of type 2 diabetes,” JAMA, vol. 302, no. 2, pp. 179-188, 2009.

[51] E. Tomas, T.-S. Tsao, A. K. Saha et al., "Enhanced muscle fat oxidation and glucose transport by ACRP30 globular domain: acetyl-CoA carboxylase inhibition and AMP-activated protein kinase activation," Proceedings of the National Academy of Sciences, vol. 99, no. 25, pp. 16309-16313, 2002.

[52] T. Yamauchi, J. Kamon, Y. Minokoshi et al., "Adiponectin stimulates glucose utilization and fatty-acid oxidation by activating AMP-activated protein kinase," Nature Medicine, vol. 8, no. 11, pp. 1288-1295, 2002.

[53] N. Ouchi, S. Kihara, T. Funahashi et al., "Reciprocal association of C-reactive protein with adiponectin in blood stream and adipose tissue," Circulation, vol. 107, no. 5, pp. 671-674, 2003.

[54] N. Maeda, I. Shimomura, K. Kishida et al., "Diet-induced insulin resistance in mice lacking adiponectin/ACRP30," Nature Medicine, vol. 8, no. 7, pp. 731-737, 2002.

[55] N. Sattar, G. Wannamethee, N. Sarwar et al., "Adiponectin and coronary heart disease," Circulation, vol. 114, no. 7, pp. 623-629, 2006.

[56] Y. Iwashima, T. Katsuya, K. Ishikawa et al., "Нypoadiponectinemia is an independent risk factor for hypertension," Hypertension, vol. 43, no. 6, pp. 1318-1323, 2004.

[57] S. J. Hong, C. G. Park, H. S. Seo, D. J. Oh, and Y. M. Ro, "Associations among plasma adiponectin, hypertension, left ventricular diastolic function and left ventricular mass index," Blood Pressure, vol. 13, no. 4, pp. 236-242, 2004.

[58] T. Pischon, C. J. Girman, G. S. Hotamisligil et al., "Plasma adiponectin levels and risk of myocardial infarction in men," JAMA, vol. 291, no. 14, pp. 1730-1737, 2004.

[59] N. Ouchi, S. Kihara, Y. Arita et al., "Novel modulator for endothelial adhesion molecules," Circulation, vol. 100, no. 25, pp. 2473-2476, 1999.

[60] C. Kobashi, M. Urakaze, M. Kishida et al., "Adiponectin inhibits endothelial synthesis of interleukin-8," Circulation Research, vol. 97, no. 12, pp. 1245-1252, 2005.

[61] N. Ouchi, S. Kihara, Y. Arita et al., "Adiponectin, an adipocyte-derived plasma protein, inhibits endothelial NF- $\kappa \mathrm{B}$ signaling through a cAMP-dependent pathway," Circulation, vol. 102, no. 11, pp. 1296-1301, 2000.

[62] N. Ouchi, A. Higuchi, K. Ohashi et al., "Sfrp5 is an antiinflammatory adipokine that modulates metabolic dysfunction in obesity," Science, vol. 329, no. 5990, pp. 454-457, 2010.

[63] E. Ernst, "Methodological aspects of traditional Chinese medicine (TCM)," Annals of the Academy of Medicine, Singapore, vol. 35, no. 11, pp. 773-774, 2006.

[64] W. Yao, H. Yang, and G. Ding, "Mechanisms of Qi-blood circulation and Qi deficiency syndrome in view of blood and interstitial fluid circulation," Journal of Traditional Chinese Medicine, vol. 33, no. 4, pp. 538-544, 2013.

[65] The Society of Korean Medicine Rehabilitation, Korean Regabilitation Medicine Ver, vol. 4, Koonja, pp. 303-304, Seoul, South Korea, 2015.
[66] J. J. T. Liaw and P. V. Peplow, "Effect of electroacupuncture on inflammation in the obese zucker fatty rat model of metabolic syndrome," Journal of Acupuncture and Meridian Studies, vol. 9, no. 2, pp. 73-79, 2016.

[67] J. J. T. Liaw and P. V. Peplow, "Effects of electroacupuncture on pro-/anti-inflammatory adipokines in serum and adipose tissue in lean and diet-induced obese rats," Journal of Acupuncture and Meridian Studies, vol. 9, no. 2, pp. 65-72, 2016.

[68] J. Johansson, L. Mannerås-Holm, R. Shao et al., "Electrical vs manual acupuncture stimulation in a rat model of polycystic ovary syndrome: different effects on muscle and fat tissue insulin signaling," PLoS One, vol. 8, no. 1, Article ID e54357, 2013.

[69] J. J. T. Liaw and P. V. Peplow, "Differential effect of electroacupuncture on inflammatory adipokines in two rat models of obesity," Journal of Acupuncture and Meridian Studies, vol. 9, no. 4, pp. 183-190, 2016.

[70] P. V. Peplow and G. T. Z. McLean, "Repeated electroacupuncture: an effective treatment for hyperglycemia in a rat model," Journal of Acupuncture and Meridian Studies, vol. 8, no. 2, pp. 71-76, 2015.

[71] P. V. Peplow, "Repeated electroacupuncture in obese zucker diabetic fatty rats: adiponectin and leptin in serum and adipose tissue," Journal of Acupuncture and Meridian Studies, vol. 8, no. 2, pp. 66-70, 2015.

[72] R. Yan, X. Liu, J. Bai, J. Yu, and J. Gu, "Influence of catgut implantation at acupoints on leptin and insulin resistance in simple obesity rats," Journal of Traditional Chinese Medicine, vol. 32, no. 3, pp. 477-481, 2012.

[73] H. J. Jang, H. S. Lee, and J. M. Lee, "Effect of Hagocho (Prunella vularis L.), Gamgook (Chrysanthemum indicum L.) and Galgeun (Puerariae radix) aua-acupuncture at gokji (LI 11) and Joksamri (ST 36) on lowering lipid effect, oxidative capacity, concentration of TNF-a, IL-6, leptin and histological consideration in hyperlipidemic rat," Journal of Acupuncture and Meridian Studies, vol. 24, no. 4, pp. 201219, 2007.

[74] M. W. Kim, H. H. Lim, and Y. K. Song, "Anti-obesity effect of Wild Ginseng complex pharmacopuncture on adipocyte and high fat diet-induced obese C57BL/6J mice," Journal of Rehabilitation Medicine, vol. 22, no. 2, pp. 67-90, 2012.

[75] J. H. Ji and J. M. Lee, "Effects of distilled Phaseoli Semen rubra herbal acupuncture on lipid composition, liver function, anti-oxidant capacity and molecular biological aspects in obese rats induced high fat diet," Journal of Pharmacopuncture, vol. 8, no. 2, pp. 67-82, 2005.

[76] L. A. Ismail, A. A. Ibrahim, G. A. Abdel-Latif et al., "Effect of acupuncture on body weight reduction and inflammatory mediators in Egyptian obese patients," Open Access Macedonian Journal of Medical Sciences, vol. 3, no. 1, pp. 85-90, 2015.

[77] F. Güçel, B. Bahar, C. Demirtas, S. Mit, and C. Çevik, "Influence of acupuncture on leptin, ghrelin, insulin and cholecystokinin in obese women: a randomised, shamcontrolled preliminary trial," Acupuncture in Medicine, vol. 30, no. 3, pp. 203-207, 2012.

[78] A. Firouzjaei, G. C. Li, N. Wang et al., "Comparative evaluation of the therapeutic effect of metformin monotherapy with metformin and acupuncture combined therapy on weight loss and insulin sensitivity in diabetic patients," Nutrition \& Diabetes, vol. 6, p. e209, 2016.

[79] P. M. Tjan, A. Srilestari, K. Abdurrohim et al., "Combination therapy efficacy of catgut embedding acupuncture and diet 
intervention on interleukin-6 levels and body mass index in obese patients," Journal of Physics: Conference Series, vol. 884, Article ID 012131, 2017.

[80] K. Suruga, T. Tomita, K. Kadokura et al., "Rhus verniciflua leaf extract suppresses obesity in high-fat diet-induced obese mice," Food \& Nutrition Research, vol. 63, 2019.

[81] Z. Liao, X. Chen, and M. Wu, "Antidiabetic effect of flavones from Cirsium japonicum DC in diabetic rats," Archives of Pharmacal Research, vol. 33, no. 3, pp. 353-362, 2010.

[82] K. Azushima, K. Tamura, H. Wakui et al., "Bofu-tsu-shosan, an oriental herbal medicine, exerts a combinatorial favorable metabolic modulation including antihypertensive effect on a mouse model of human metabolic disorders with visceral obesity," PLoS One, vol. 8, no. 10, Article ID e75560, 2013.

[83] C.-H. Lin, Y.-H. Kuo, and C.-C. Shih, "Effects of BofuTsusho-San on diabetes and hyperlipidemia associated with AMP-activated protein kinase and glucose transporter 4 in high-fat-fed mice," International Journal of Molecular Sciences, vol. 15, no. 11, pp. 20022-20044, 2014.

[84] S. Akagiri, Y. Naito, H. Ichikawa et al., "Bofutsushosan, an oriental herbal medicine, attenuates the weight gain of white adipose tissue and the increased size of adipocytes associated with the increase in their expression of uncoupling protein 1 in high-fat diet-fed male KK/Ta mice," Journal of Clinical Biochemistry and Nutrition, vol. 42, no. 2, pp. 158-166, 2008.

[85] S. Kobayashi, Y. Kawasaki, T. Takahashi et al., "Mechanisms for the anti-obesity actions of bofutsushosan in high-fat dietfed obese mice," Chinese Medical Journal, vol. 12, no. 8, 2017.

[86] A. Hussain, M. K. Yadav, S. Bose et al., "Daesiho-tang is an effective herbal formulation in attenuation of obesity in mice through alteration of gene expression and modulation of intestinal microbiota," PLoS One, vol. 11, no. 11, Article ID e0165483, 2016.

[87] A. Ansari, S. Bose, M. K. Yadav et al., "CST, an herbal formula, exerts anti-obesity effects through brain-gut-adipose tissue Axis modulation in high-fat diet fed mice," Molecules, vol. 21, no. 11, 2016.

[88] Y. M. Koh, S. W. Jang, and T. W. Ahn, "Anti-obesity effect of Yangkyuksanwha-tang in high-fat diet-induced obese mice," BMC Complementary and Alternative Medicine, vol. 19, p. 246, 2019.

[89] Y. Y. Sung, D. S. Kim, G. Y. Choi et al., "Dohaekseunggi-tang extract inhibits obesity, hyperlipidemia, and hypertension in high-fat diet-induced obese mice," BMC Complementary and Alternative Medicine, vol. 14, p. 372, 2014.

[90] J. Y. Choi, Y. J. Kim, S. J. Cho et al., "Metabolic effect of an oriental herbal medicine on obesity and its comorbidities with transcriptional responses in diet-induced obese mice," International Journal of Molecular Sciences, vol. 18, no. 4, p. 747, 2017.

[91] S.-H. Kim, H.-S. Park, M. J. Hong et al., "Tongqiaohuoxue decoction ameliorates obesity-induced inflammation and the prothrombotic state by regulating adiponectin and plasminogen activator inhibitor-1," Journal of Ethnopharmacology, vol. 192, pp. 201-209, 2016.

[92] K. Azushima, K. Tamura, S. Haku et al., "Effects of the oriental herbal medicine Bofu-tsusho-san in obesity hypertension: a multicenter, randomized, parallel-group controlled trial (ATH-D-14-01021.R2)," Atherosclerosis, vol. 240, no. 1, pp. 297-304, 2015.

[93] Korean Acupuncture \& Moxibustion Medicine Society Textbook Compilation Committee, The Acupuncture and Moxibustion Medicine, Jipmoondang, pp. 5-17, Seoul, South Korea, 2012.
[94] L. Jiao and Z. H. Chi, "Electroacupuncture for treatment of simple obesity complicated with fatty liver," Zhongguo Zhen Jiu, vol. 28, no. 3, pp. 183-186, 2008.

[95] C.-Y. Huang, M.-Y. Choong, and T.-S. Li, "Treatment of obesity by catgut embedding: an evidence-based systematic analysis," Acupuncture in Medicine, vol. 30, no. 3, pp. 233-234, 2012.

[96] M. W. Kim, Y. K. Song, and H. H. Lim, "Study of experimentations and clinical trials' trends for obesity treatment using pharmacopuncture," Journal of Korean Oriental Association for Study of Obesity, vol. 11, no. 1, pp. 47-60, 2011.

[97] M.-H. Nam, S.-W. Lee, H.-Y. Na et al., "Herbal acupuncture for the treatment of obesity," Journal of Acupuncture and Meridian Studies, vol. 9, no. 2, pp. 49-57, 2016.

[98] J. G. Kang and C.-Y. Park, "Anti-obesity drugs: a review about their effects and safety," Diabetes \& Metabolism Journal, vol. 36, no. 1, pp. 13-25, 2012.

[99] H. C. Lee, "Anti complications of surgery for morbid obesity: laparoscopic adjustable gastric banding," Journal of Metabolic and Bariatric Surgery, vol. 1, no. 2, pp. 67-72, 2012.

[100] J. S. Lee and S. H. Lee, "The reductive effects of oriental medicine on the body fat and abdominal obesity," Journal of Korean Medicine for Obesity Research, vol. 1, no. 1, pp. 33-42, 2001. 